\title{
Potential of Hanjeli (Coix lacryma-jobi) essential oil in preventing SARS-CoV-2 infection via blocking the Angiotensin Converting Enzyme 2 (ACE2) receptor
}

\author{
Diky Setya Diningrat $\cdot$ Ayu Nirmala Sari $\cdot$ Novita Sari Harahap $\cdot$ Kusdianti
}

Received: 14 September 2021 / Revised: 27 December 2021 / Accepted: 27 December 2021

(c) Korean Society for Plant Biotechnology

\begin{abstract}
Covid-19 is an ongoing pandemic as we speak in 2022. This infectious disease is caused by the SARS-CoV-2 virus, which infects cells by binding to the angiotensinconverting enzyme 2 (ACE2) receptor on the cell surface. Thus, strategies that inhibit the binding of SARS-CoV-2 to the ACE2 receptor can stop this contagion. Hanjeli (Coix lacryma-jobi) essential oil contains many bioactive compounds, including dodecanoic acid; tetradecanoic acid; 7-Amino-8imino-2-(2-imino-2H-chromen-3-yl); and 1,5,7,10-tetraazaphen-9-one. These compounds suppress viral replication and may prevent Covid-19. Accordingly, this study assessed whether, these four limonoid compounds can block the ACE2 receptor. To this end, their physicochemical properties were predicted using Lipinski's "rule of five" on the SwissADME website, and their toxicity was assessed using the online tools ProTox and pkCSM. Additionally, their interactions with the ACE2 receptor were predicted via molecular docking using Autodock Vina. All the four compounds satisfied the "rule of five" and tetradecanoic acid was predicted to have a higher affinity than the comparison compound remdesivir and the original ligand of ACE2. Molecular docking results suggested
\end{abstract}

\footnotetext{
D. S. Diningrat $(\bowtie)$

Department of Biology, Faculty of Mathematics and Natural Sciences, Universitas Negeri Medan, Indonesia e-mail: dikysd@unimed.ac.id
}

\section{A. N. Sari}

Biology Study Program, Faculty of Science and Technology, UIN Ar-Raniry Banda Aceh, Indonesia

\section{N. S. Harahap \\ Department of Sports Science, Faculty of Sports Science, Universitas Negeri Medan, Indonesia}

Kusdianti

Department of Biology, Faculty of Mathematics and Natural Sciences Education, Indonesian University of Education, Bandung, Indonesia that the compounds from hanjeli essential oil interact with the active site of the ACE2 receptor similarly as the original ligand and remdesivir. In conclusion, hanjeli essential oil contains compounds predicted hinder the interaction of SARS-CoV-2 with the ACE2 receptor. Accordingly, our data may facilitate the development of a phytomedical strategy against SARSCoV-2 infection.

Keywords Antiviral, ACE2, ACE2 Inhibitor, Coix lacrymajobi, Essential Oil

\section{Introduction}

Viruses considered as biological chemicals are often referred to as meta organisms. Several diseases caused by viruses have caused global outbreaks. At this time, the world has been in shock with a new virus that is endemic and even causing a pandemic, namely SARS-CoV-2 (Rothan and Byrareddy 2020). This virus has phylogenetic similarities with other types of coronavirus (Helmy et al. 2020). The recent studies have shown that the SARS-CoV-2 virus is more amenable to the human Angiotensin Converting Enzyme 2 (hACE2) receptor than SARS-CoV. This may cause the rate of human-to-human transmission of SARS-CoV-2 to be higher than that of SARS$\mathrm{CoV}$ (Wan et al. 2020).

The World Health Organization (WHO) determined the status of Covid-19 as a pandemic on March 11, 2020 (WHO 2020). The unavailability of appropriate treatment therapy for Covid-19 patients has caused the death rate from this pandemic to be quite high (Bimonte et al. 2020). There are several classes of drugs that are in clinical trials regarding their potential against SARS-CoV-2 such as RNA polymerase inhibitors (remdesivir and favipiravir), protease 4 inhibitors (lopinavir/ritonavir), aminoquinolines (chloroquine and its hydroxyl derivatives) and anti-inflammatory agents. (corti- 
costeroids). Some of these synthetic drugs are currently used in therapeutic guidelines for Covid-19 positive patients (Neldi and Suharjono 2020). However, according to WHO (2020) these drugs have not been able to reduce patient mortality rates.

The current COVID-19 treatment therapy in China does not only rely on synthetic drugs, but also herbal medicines. Clinical evidences from various studies of herbal plants in the treatment of the coronavirus (SARS-CoV) have shown the significant results, and supports the idea that herbal medicines have beneficial effects on the treatment and prevention of epidemic diseases (Yang et al. 2020). Based on these respects, various studies currently focus on the potential of medicinal plants as SARS-CoV-2 antivirals. Various studies have stated that bioactive compounds in plants have anti-inflammatory, antibacterial, antioxidant, antifungal and even antiviral activities. Thus, medicinal plants are considered as the fruitful sources, one of which is considered as the SARS-CoV-2 antiviral (Borkotoky and Banerjee 2020).

Hanjeli plants have complex metabolites including tannins, alkaloids, flavonoids, anthracenoids, steroids and carotenoids which are suspected to have antiviral activity (Diningrat et al. 2020). Hanjeli essential oil has been known to contain Dodecanoic acid; Tetradecanoic acid; 7-Amino-8-imino-2-(2-imino2H-chromen-3-yl); and 1,5,7,10-tetraaza-phenanthren-9-one. The silico study of the bioactive hanjeli essential oil compound showed that the compound has potential as an antiviral corona (Diningrat et al. 2020). Based on the results of these studies, to determine the potential for bioactive compounds of hanjeli plant essential oil as an antiviral for SARS-CoV-2, it is necessary to conduct research in silico.

\section{SARS-CoV-2}

Coronaviruses are single-stranded RNA virus that can infect a wide variety of animals including birds, guinea pigs, mammalian species and humans. These viruses differ due to their ability to mutate rapidly, change tissue tropism, bypass species barrier, and adapt to different epidemiological situations (Decaro and Lorusso 2020). They have a particle size of $120 \sim 160 \mathrm{~nm}$. They also belong to the subfamily of Orthocoronavirinae under the family of Coronaviridae (Wu et al. 2020). SARS-CoV-2 is part of the genus -CoV. Based on phylogenetic analysis, it was found that SARS-CoV-2 harbored one gene (ORF8) which is phylogenetically closest to SARSlike CoV, but differs in lineage (Ren et al. 2020).

The following is the taxonomy of SARS-CoV-2 based on the results of the Coronaviridae Study Group (CSG), which is part of the International Committee on Taxonomy of Viruses
(Coronaviridae Study Group of the International Committee on Taxonomy of Viruses, 2020):

$\begin{array}{ll}\text { Kingdom } & : \text { Riboviria } \\ \text { Order } & : \text { Nidovirales } \\ \text { Suborder } & : \text { Cornidovirineae } \\ \text { Family } & \text { : Coronaviridae } \\ \text { Subfamily } & \text { : Orthocoronavirinae } \\ \text { Genus } & : \text { Bethacoronavirus } \\ \text { Subgenus } & : \text { Sarbecovirus } \\ \text { Species } & : \text { SARS-related coronavirus } \\ \text { Individual } & \text { : SARS-CoV-2 Wuhan-Hu-1 }\end{array}$

SARS-CoV-2 displays an excellent affinity for hACE2 which could bind SARS-CoV-2 in both open and closed conformations (Wrapp et al. 2020). The RBD and hACE2 spike complex showed that the binding capacity of SARS$\mathrm{CoV} 2$ protein with hACE2 is significantly higher than that of SARS- CoV (Xu et al. 2020). SARS-CoV-2 enters target cells via membrane fusion or endocytosis. After the entry of the virus into the host cell, viral RNA enters the cytoplasm and is cleaved (proteolysis) to form a transcription-replication complex. The viral particles are then released from the infected cells by exocytosis ( $\mathrm{Li}$ et al. 2021).

\section{Hanjeli Plant}

Hanjeli plant (C. lacryma-jobi) is one of the plants from the Poaceae family. Usually, it is used as food and animal feeds. This plant usually grows wild, so it is easy to find it. The potential use of Hanjeli is very high because a few people have used this plant for specific research, for example, to know the benefits of its bioactive compound content. There are two varieties planted by people, namely, C. lacryma-jobi variety of lacryma-jobi and $C$. lacryma-jobi ma yuen variety. The former has a hard white shell, oval shape and is used as beads, while the latter as the other variety is eaten by people and also part of the medical tradition in China (Diningrat et al. 2020).

The essential oil is one of the extraction products widely used in the world of pharmacology as a medicine for the certain diseases. In general, many essential oils are produced from the seeds of the average plant. Usually, essential oils are produced through the distillation process - the process of pulling or extracting compounds that evaporate with water as the solvent. Then, to see the content of compounds contained in the essential oil, it is important to carry out a gas chromatography process

The secondary metabolites have the main task of being a weapon to survive or protect themselves against other organisms. In contrast to animals, the results of plant metabolism are 
accumulated in certain parts of plants such as vacuoles, specialized cells or glands or probably followed by catabolism processes. The recent studies have shown that Hanjeli seed and root essential oil has antiviral potential (Diningrat et al. 2020).

\section{ACE2 receptors}

ACE2 is a type 1 membrane integral glycoprotein that is expressed and activated in almost all human tissues (Homo sapiens). The highest expression of ACE2 was observed in the respiratory tract (lungs), gastrointestinal tract and heart. ACE2 has a nucleotide base sequence similarity of $42 \%$ to angiotensin-converting enzyme (ACE) (Wiese et al. 2020). This causes ACE and ACE2 to have homologous protein characters, but both have different substrate specificities (Gheblawi et al. 2020). The similarity of nucleotide base sequences on the catalytic sites of ACE and ACE2 was $61 \%$. ACE2 functions as a carboxypeptidase, cleaving a single hydrophobic/base residue from the C-terminus of its substrate. ACE2 efficiently hydrolyzes the potent vasoconstrictor of angiotensin II to be angiotensin (1-7). ACE2 is not widely found in the blood circulation, but this enzyme is widely expressed on the epithelial cell membranes of the lungs and digestive tract, where the region was the main route of the virus entry into the human body [18]. The presence of excessive ACE2 is an opportunity for the entry of SARS$\mathrm{CoV}-2$ and the beginning of its pathogenesis. The mechanism of ACE2 inhibition or the expression suppression of this enzyme is one of the targets in its control (McMurray et al. 2020; Zheng et al. 2020).

\section{Material and Method}

\section{Research Method}

This research was a pre-experimental research type of computer-based design conducted in silico from six bioactive compounds of hanjeli plant essential oil named Dodecanoic acid; Tetradecanoic acid; 7-Amino-8-imino-2-(2-imino-2Hchromen-3-yl); and 1,5,7,10-tetraaza-phenanthren-9-one against the ACE2 receptor using Chem Bio Draw Ultra software version 19.0, Chem 3D Ultra version 19.0, Discovery Studio Visualizer, SwissADME, Autodock Vina, MGLTools, PyMol, pkCSMOnline Tools, Protox Online Tool and Microsoft Excel.

Research Time and Place

This research was carried out from February to April 2021 at the Laboratory of the Biology Study Program, Faculty of Mathematics and Natural Sciences, State University of Medan. Multifunction Laboratory of UIN Ar Raniry Banda Aceh and Laboratory of the Department of Biology, Faculty of Mathematics and Natural Sciences, Universitas Pendidikan Indonesia, Bandung.

Research Tools and Materials Research Tools

This study used a device consisting of hardware and software. The hardware used was a set of Lenovo Yoga Laptops with Intel(R) Core(TM) i7 processor specifications, 16 GB RAM, and $500 \mathrm{~GB}$ hard disk. Meanwhile, the software used was the Windows 10 Pro operating system, Chem Bio Draw Ultra version 19.0, Chem 3D Ultra version 19.0, Discovery Studio Visualizer, SwissADME, AutoDock Vina, MGLTools, PyMol, pkCSM Online Tool, Protox Online Tool, and Microsoft Excel 2013.

\section{Results And Discussions}

The research on the antiviral potential of bioactive compounds of hanjeli plant essential oil (Coix lacryma-jobi) was held using an in silico computational method. The silico method is often used as an initial screening in the discovery of new drugs. The scope of the in silico method used is a docking study (Hussein and Elkhair 2021). The choice of docking study was based on the role of molecular docking, which aims to determine the bond between the ligand and the receptor. This method could play an important role in the success of structural drug design. In addition, this method has the advantage of being able to save costs and time for finding new drugs (Seffernick and Lindert 2020).

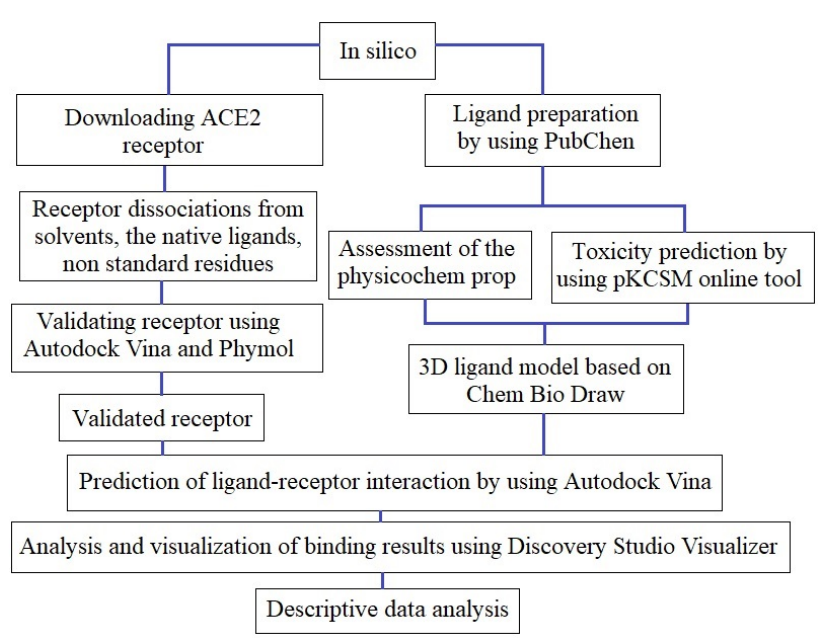

Fig. 1 Research flow 
Table 1 Structure of the ACE2 downloaded from the Protein Data Bank

\begin{tabular}{ccclc}
\hline No & Identity & $\begin{array}{c}\text { The number of } \\
\text { sub unit }\end{array}$ & Bound ligand & Resolution $(\AA)$ \\
\hline 1 & 1 R42 & 3 & $\begin{array}{l}\text { Dodecanoic acid; tetradecanoic; acid; 7-Amino-8-imino-2-(2-imino- } \\
\text { 2H-chromen-3-yl); and 1,5,7,10-tetraaza-phenanthren-9-one. }\end{array}$ & 22 \\
\hline
\end{tabular}

In this study, bioactive compounds of hanjeli plant essential oil were used, namely Dodecanoic acid; Tetradecanoic acid; 7-Amino-8-imino-2-(2-imino-2H-chromen-3-yl); and 1,5,7, 10-tetraaza-phenanthren-9-one. These compounds are commonly found in the roots and seeds of the hanjeli plant [9]. The research on bioactive compounds of hanjeli plant essential oil was conducted to determine whether these compounds had the potential as antiviral SARS-CoV-2 in silico. An approach method carried out included the testing of physicochemical properties, toxicity and prediction of activity between ligands and receptors by molecular docking.

\section{In Silico Sample Preparation}

Sample preparation used in the in silico process was an important step to reach an optimal result (Maia et al. 2020). The in silico sample preparation stage included the preparation of the ligand and receptor (target proteins) used in the study (Kanakaveti et al. 2020). The samples prepared in this study were the ACE2 receptor (target protein) with PDBid code: 1R42 and the compounds tested were Dodecanoic acid; Tetradecanoic acid; 7-Amino-8-imino-2-(2-imino-2H-chromen3 -yl); and 1,5,7,10-tetraaza-phenanthren-9-one.

\section{ACE2 Receptor Download}

The first step in this research was downloading the ACE2 receptor as the target protein. The receptor download was done through the Protein Data Bank database (PDB; http:// www.rscb.org.pd) in .pdb format. The downloaded receptor was a macromolecule with the identity (PDBid) 1R42. This structure had three different types of subunits (hetero-3-mer) with native ligands as a result of electron microscopy. The conditions and qualities of the downloaded ACE2 structures were listed in Table 1.

The Protein Data Bank shows ACE2 receptor a macromolecular structure bound to the native ligands. This complex (1R42) consists of three chains (sub units) namely nsp 7 (C chain), nsp 8 (B chain) and nsp 12. A chain also known as ACE2 (Yin et al. 2020).

\section{SARS-CoV-2 Receptor Preparation}

While downloading the receptor with the identity of $1 \mathrm{R} 42$

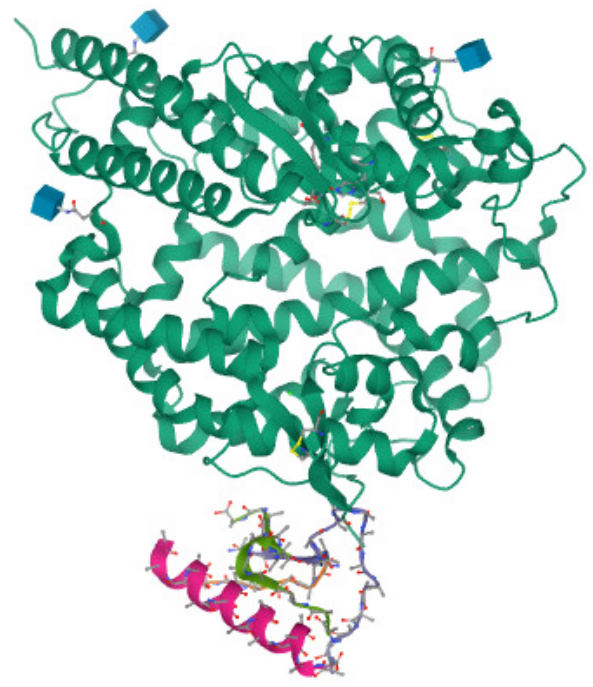

Fig. 2 1R42 receptor based on Discovery Studio Visualizer

through the Protein Data Bank, the structure was in the form of a single unit with native ligands, water molecules and other non-standard, which were remnants of the previous protein crystallization. These non-standard residues must be removed so as not to interfere with the belay process. The non-standard residues removed were nsp 7 and nsp 8 . These residues in this case were a complex entity with ACE2 (nsp 12). The native ligand on the receptor also needed to be removed because the ligand was bound to the active site of the receptor, so it can prevent other ligands from binding. Meanwhile, the presence of water molecules would also affect the results of binding, so it needs to be removed (Maia et al. 2020; Yin et al. 2020). The separated structure was saved in .pdb format.

The next step after the separation of the macromolecular chain was the optimization phase of the macromolecular structure. At this stage, the MGL Tools application was used. The optimization steps carried out again were by removing water molecules and adding hydrogen atoms. The removal of water molecules aims to prevent water from connecting with compounds that would be tethered to the receptor (Zhao and Tajkhorshid 2021). While the addition of hydrogen atoms needed to be done because the presence of hydrogen affected the results of the bonding with the formation of hydrogen bonds. After that, Kollman charges were added to extend the load on the amino acid residue, namely electrostatic potential energy. Furthermore, the receptor was added gasteiger charge 


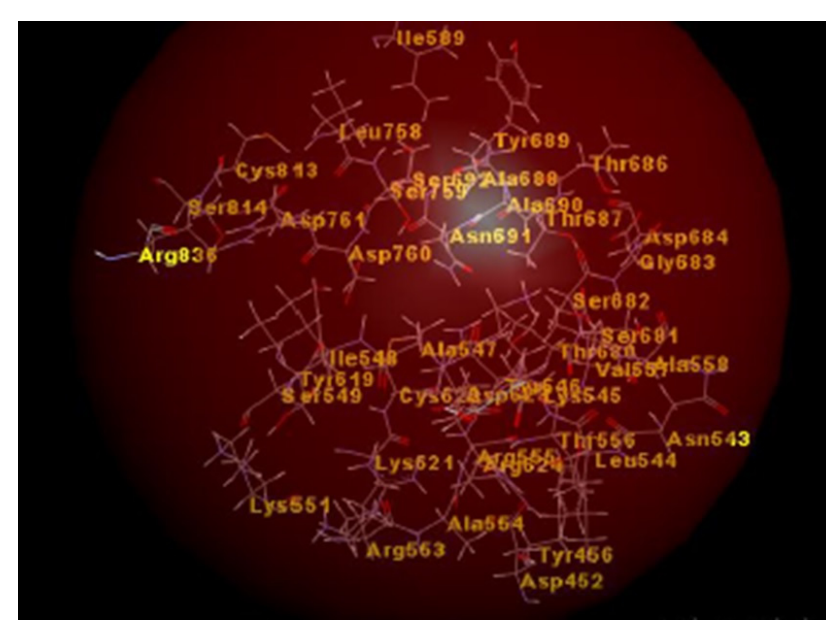

Fig. 3 1R42 receptor binding area based on Discovery Studio Visualizer

which aimed to adjust to the molecular anchoring environment (Goodsell et al. 2021). The structure was then saved in.pdbqt format.

Determination of Binding Site and Grid Box

Docking studies generally begin with determining the binding site. This is because in general proteins had a limited binding region. The size of (grid box) and protein binding sites can be visualized in the docking application and can be adjusted interactively. Optionally, the residue in the binding area is flexible during the docking process (Valdés-Tresanco et al. 2020). While determining the binding site and grid box, the Discovery Studio Visualizer application and MGL Tools were utilized. In the Discovery Studio Visualizer application, the binding site could be determined based on structural data obtained from Protein Data Bank, the Discovery Studio Visualizer application and based on the previous research journals. The amino acid residues Lys545, Arg553, Asp623, Asn691, Ser682 and Leu759 made interactions between proteins and remdesivir (Koulgi et al. 2020; Dahab et al. 2020). The determination of binding sites based on the $1 \mathrm{R} 42$ receptor was reviewed based on amino acid residues located around the native ligand receptor, where the position of native ligand is allegedly the active side of the receptor (Yin et al. 2020). Based on this, a suitable binding site was found and then the center size $\mathrm{x}=91.776, \mathrm{y}=91.56$ and $\mathrm{z}=104,863$. The next step was to determine the grid box using the MGL Tools application. The determination of the grid box aimed to decide the size of the area to be docked with certain compounds (Dahab et al. 2020). Based on the results of MGL Tools, the grid box size was $\mathrm{x}=8, \mathrm{y}=8$, and $\mathrm{z}=10$ with a space of 1 . The results of determining the binding site and grid box were then stored in .txt format as data used in the docking process.

Preparation of Test Compound

Construction of 2D, 3D Compound Structures and SMILES Code

$2 \mathrm{D}$ and $3 \mathrm{D}$ compound structures were created using the ChemDraw application (Pratama et al. 2020). The structure of the compound to be tested was previously drawn using the ChemDraw 2D version 19.0 application. The structure of the compounds drawn included dodecanoic compounds, acid; Tetradecanoic acid; 7-Amino-8-imino-2-(2-imino-2H-chromen3-yl); and 1,5,7,10-tetraaza-phenanthrene-9-one. In addition,

Table 2 3D structures of the test and comparison compound

\begin{tabular}{|c|c|}
\hline Compound name & 3D structure \\
\hline $\begin{array}{l}\text { Dodecanoic acid } \\
\text { 1S/C24H41NO5S/c1-3-5-7-8-9-10-11-12-13-14-15-23(24(26)27)30-22-18-16-21(17-19-2 } \\
\text { 2)25-31(28,29)20-6-4-2/h16-19,23,25H,3-15,20H2,1-2H3,(H,26,27) }\end{array}$ & \\
\hline $\begin{array}{l}\text { Tetradecanoic acid } \\
\text { 1S/C14H28O2/c1-2-3-4-5-6-7-8-9-10-11-12-13-14(15)16/h2-13H2,1H3,(H,15,16) }\end{array}$ & \\
\hline $\begin{array}{l}\text { 7-Amino-8-imino-2-(2-imino-2H-chromen-3-yl) } \\
\text { 1S/C21H1 1CIN2O3S/c22-13-5-6-18-12(7-13)9-15(19(23)26-18)20-24-16(10-28-20)14-8- } \\
\text { 11-3-1-2-4-17(11)27-21(14)25/h1-10,23H }\end{array}$ & \\
\hline $\begin{array}{l}\text { 1,5,7,10-tetraaza-phenanthren-9-one } \\
\text { 1S/C10H6N4/c1-2-11-5-7-6-14-10-9(8(1)7)12-3-4-13-10/h1-6H }\end{array}$ & \\
\hline
\end{tabular}


Table 3 SMILES code structures of the test and comparison compound

\begin{tabular}{ll}
\hline Name & SMILES code \\
\hline Dodecanoic acid & CCCCCCCCCCC $(=\mathrm{O}) \mathrm{O}$ \\
Tetradecanoic acid & $\mathrm{CCCCCCCCCCCCC}(=\mathrm{O}) \mathrm{O}$ \\
8-Amino-8-imino-2-(2-imino-2H-chromen-3-yl) & $\mathrm{C} 1=\mathrm{CC}=\mathrm{C} 2 \mathrm{C}(=\mathrm{C} 1) \mathrm{C}=\mathrm{C}(\mathrm{C}(=\mathrm{O}) \mathrm{O} 2) \mathrm{C} 3=\mathrm{CSC}(=\mathrm{N} 3) \mathrm{C} 4=\mathrm{CC} 5=\mathrm{C}(\mathrm{C}=\mathrm{CC}(=\mathrm{C} 5) \mathrm{Cl}) \mathrm{OC} 4=\mathrm{N}$ \\
$1,5,7,10$-tetraaza-phenanthren-9-one & $\mathrm{C} 1=\mathrm{CC}=\mathrm{C} 2 \mathrm{C}(=\mathrm{C} 1) \mathrm{C}=\mathrm{C}(\mathrm{C}(=\mathrm{O}) \mathrm{O} 2) \mathrm{C} 3=\mathrm{CSC}(=\mathrm{N} 3) \mathrm{C} 4=\mathrm{CC} 5=\mathrm{C}(\mathrm{C}=\mathrm{CC}(=\mathrm{C} 5) \mathrm{Cl}) \mathrm{OC} 4=\mathrm{N}$ \\
Remdesivir & $\mathrm{CCC}(\mathrm{CC}) \mathrm{COC}(=\mathrm{O}) \mathrm{C}(\mathrm{C}) \mathrm{NP}(=\mathrm{O})(\mathrm{OCC} 1 \mathrm{C}(\mathrm{C}(\mathrm{C}(\mathrm{O} 1)(\mathrm{C \# N}) \mathrm{C} 2=\mathrm{CC}=\mathrm{C} 3 \mathrm{~N} 2 \mathrm{~N}=\mathrm{CN}=\mathrm{C} 3 \mathrm{~N}) \mathrm{O})$ \\
& $\mathrm{O}) \mathrm{OC} 4=\mathrm{CC}=\mathrm{CC}=\mathrm{C} 4$ \\
\hline
\end{tabular}

Table 4 Energy minimization of test and comparison compounds

\begin{tabular}{lcccc}
\hline \multirow{2}{*}{ Compound } & \multicolumn{4}{c}{ Energy Minimization (kcal/mol) } \\
\cline { 2 - 5 } & Replication 1 & Replication 2 & Replication 3 & 741,15 \\
\hline Dodecanoic acid & 741,15 & 741,15 & 153,38 & 741,15 \\
Tetradecanoic acid & 153,38 & 153,38 & 153,38 \\
9-Amino-8-imino-2-(2-imino-2H-chromen-3-yl & 132,93 & 132,93 & 132,93 & 132,93 \\
1,5,7,10-tetraaza-phenanthren-9-one & 150,70 & 150,69 & 150,69 & 150,69 \\
Remdesivir & $-1,94$ & $-1,95$ & $-1,95$ & $-1,95$ \\
\hline
\end{tabular}

Details:

Compound IUPAC Name:

- Dodecanoic acid: Dodecanoic acid

- Tetradecanoic acid: Tetradecanoic acid

- 9-Amino-8-imino-2-(2-imino-2H-chromen-3-yl):3-[2-(6-chloro-2-iminochromen-3-yl)-1,3-thiazole-4-yl]chromen-2-one

- 1,5,7,10-tetraaza-phenanthren-9-one:pyrazino[2,3-c][2,7]naphthyridine

- Remdesivir:2-ethylbutyl(2S)-2-[[[(2R,3S,4R,5R)-5-(4-aminopyrrolo[2,1-f][1,2,4]triazine-7-yl)-5-cyano-3,4-dihydroxyoxolan-2-yl]methoxyphenoxyphosphoryl]amino]propanoate

the structure of the comparison compound used, namely remdesivir, was also drawn. After the compounds had been drawn, they were visualized in 3D using the ChemDraw 3D application version 19.0. The following was a table of compound images that were tested in 3D:

Based on Table 2, it was known that the test compounds belonged to the polydentate ligand group. Moreover, ligands were grouped according to the number of donor atoms, and polydentate ligands could donate more than two atoms (Pratama et al. 2020). In the structure of the test compound, there were more than two donor atoms where the atom that acted as a donor was an oxygen atom $(\mathrm{O})$. The next step after creating 2D and 3D structures was downloading the SMILES code where each test compound as well as the comparison compound, remdesivir, was taken from the ChemDraw application. The SMILES code of each compound was used to perform physicochemical and toxicity tests. The following was a Table 3 containing the SMILES code for each test and comparison compound.

\section{Optimization of Test Compounds}

The optimization of the test compound was the final stage in the compound preparation process. This stage aimed to find the most suitable conformation with the minimum energy of a molecule to bind to other molecules, thereby stabilizing the bond arrangement during molecular docking (Godsell et al. 2021). The optimization of the tested compounds was carried out 3 times to obtain a valid minimum energy outcome of the compound. The optimized compound was then saved in.pdb format. Then, the compound was converted into pdbqt format using the MGL Tools application (Table 4).

Based on Table 4, the different minimization energy values were obtained for each compound. This was influenced by the distance, angle and torsion angle of each compound. The optimization result was an absolute value, where the negative mark indicated that the electrons were bound in the atom because of the attraction in the nucleus (Lipinski 2004).

\section{Prediction of Physicochemical Properties}

The physicochemical properties of a compound were related to the acceptable absorption of the drug and its permeability. This was the first step in the bioavailability of oral drugs (Lipinski 2004). The prediction of physicochemical properties carried out in this study employed the SwissADME 
Table 5 Predicted physicochemical properties of the test and comparison compounds

\begin{tabular}{|c|c|c|c|c|c|c|}
\hline \multirow{3}{*}{ Compound } & \multicolumn{6}{|c|}{ Parameter } \\
\hline & \multirow{2}{*}{ MW (g/mol) } & \multirow{2}{*}{$\log P$} & \multicolumn{2}{|c|}{ Hydrogen bond } & \multirow{2}{*}{$\begin{array}{c}\text { Rotating } \\
\text { atom }\end{array}$} & \multirow{2}{*}{ Suitability } \\
\hline & & & donor & acceptor & & \\
\hline Dodecanoic acid & 200.32 & 3.28 & 0 & 5 & 3 & No deviation \\
\hline Tetradecanoic acid & 228.37 & 2.54 & 0 & 6 & 3 & No deviation \\
\hline 9-Amino-8-imino-2-(2-imino-2H-chromen-3-yl & 406.8 & 2.56 & 0 & 7 & 3 & No deviation \\
\hline 1,5,7,10-tetraaza-phenanthren-9-one & 182.18 & 2.23 & 1 & 6 & 1 & No deviation \\
\hline Remdesivir & 602.58 & 0.18 & 4 & 12 & 14 & 3 deviations \\
\hline
\end{tabular}

MW (Molecular weight) $\leq 500 \mathrm{~g} / \mathrm{mol}$

Log P (Coefficient Particle) $\leq 5$

Hydrogen- bond Donor $\leq 5$

Hydrogen-b bond Acceptor $\leq 10$

Rotating Atom $\leq 10$

application with Lipinski's five law method. The results of the prediction of the physicochemical properties of the test compounds were shown on Table 5 below.

Lipinski's fifth law defines four ranges of physicochemical parameters including molecular weight of a compound $\leq 500$ $\mathrm{g} / \mathrm{mol}$, which was expressed by the number of $\mathrm{OH}$ groups and NH Donor Hydrogen Bonds $\leq 5$, Acceptor Hydrogen Bonds which were expressed by the number of $\mathrm{O}$ and $\mathrm{N}$ atoms $\leq 10$, and the logarithm value of octanol/water partition coefficient $(\log \mathrm{P}) \leq 5$. This parameter corresponds to $90 \%$ of oral drugs that had reached clinical phase II (Lipinski 2004). In further research, there were the additional parameters in the form of torsion values and compounds said to be good if they did not have more than 10 rotating hydrogen bonds (torsion) (Chagas et al. 2018).

Semipolar property of hanjeli essential oil compounds (Dodecanoic acid; Tetradecanoic acid; 7-Amino-8-imino-2(2-imino-2H-chromen-3-yl); and 1,5,7,10-tetraaza-phenanthren-9-one) happened because it contained a hydrophilic aromatic carbon ring and a polar carbonyl group. This made the compound have a larger $\log \mathrm{P}$ value. The hydrogen bond of the donor and the hydrogen bond of the acceptor were the parameters used to describe the hydrogen bonding capacity of a compound needed in the absorption process, so that if the number of hydrogen bonds in the donor was $\geq 10$ and the acceptor was $\geq 5$, the energy required in the absorption process was higher. Hydrogen bonding can affect the chemical-the physical properties of compounds such as boiling point, melting point, solubility in water, ability to form chelates and acidity.

In general, the existence of Lipinski's five law is used to describe the solubility of compounds in penetrating cells by passive diffusion (Lipinski 2004; Patrick 2001). Meanwhile, the torsion parameter is related to flexibility and drug permeability. It was reported that IV drugs usually had a higher $\mathrm{BM}$ than oral drugs and a low $\log \mathrm{P}$ value, which indicated that this structure was more likely to have a higher number of torsion bonds (Chagas et al. 2018). This caused the drug molecule to be much more structural and flexible. Based on Table 5 above, it was known that the hanjeli essential oil compound fulfilled all the five Lipinski law parameters without any deviation in each parameter. From the prediction results, it could be predicted that these compounds were easy to absorb and had good permeability.

The comparison compound in use named as remdesivir, also did not meet Lipinski's five laws because it had 3 deviations, namely a molecular weight of more than 500 $\mathrm{g} / \mathrm{mol}$, more than 10 hydrogen acceptors and more than 10 tosion. If the compound fails to comply with Lipinski's five laws, there was more likely to be a problem with the oral absorption of the drug. However, a compound that satisfies Lipinski's five law did not guarantee a good activity because this law was not related to the specific chemical structure that was present in a compound (Lipinski 2004).

\section{Ligand - Receptor Binding}

Docking molecular aims to help provide an overview of the interaction between the drug (compound) with the target receptor (Setiawan and Irawan 2017). The Docking molecular was done using Autodock Vina software. The selection of the Autodock Vina software was based on its better ability than Autodock 4. The advantage of this program is that it has better speed and accuracy compared to the previously developed program, Autodock 4, thereby shortening the running time during docking (Godsell et al. 2021). 
Table 6 RMSD re-docking of the native ligand and 1R42 (ACE2) receptor

\begin{tabular}{|c|c|c|c|c|c|c|c|}
\hline \multirow{2}{*}{ Compound } & \multirow{2}{*}{ Receptor name } & \multirow{2}{*}{ Center } & \multirow{2}{*}{$\begin{array}{l}\text { Grid box } \\
(\AA)\end{array}$} & \multicolumn{4}{|c|}{ RMSD Value $(\AA)$} \\
\hline & & & & I & II & III & Average \\
\hline \multirow{3}{*}{$\begin{array}{l}\text { 2-acetamido-2-deoxy-beta-D- } \\
\text { glucopyranose }\end{array}$} & RNA dependent & X: 91.776 & $X: 8$ & & & & \\
\hline & RNA polymerase & Y: 91.56 & Y: 8 & 1.236 & 1.201 & 1.203 & 1.213 \\
\hline & PDB ID : 1R42 & $Z: 104.863$ & $Z: 10$ & & & & \\
\hline
\end{tabular}

Table 7 Binding results based on Autodock Vina

\begin{tabular}{lcccc}
\hline \multirow{2}{*}{ Compound } & \multicolumn{4}{c}{ Binding affinity (kcal/mol) } \\
\cline { 2 - 5 } & Replication I & Replication II & Replication III & Average \\
\hline Dodecanoic acid & -5.5 & -5.5 & -5.5 & -5.5 \\
Tetradecanoic acid & -5.8 & -5.8 & -5.8 & -5.8 \\
9-Amino-8-imino-2-(2-imino-2H-chromen-3-yl) & -5.9 & -5.9 & -5.9 & -5.9 \\
1,5,7,10-tetraaza-phenanthren-9-one & -6.4 & -6.4 & -6.4 & -6.4 \\
Remdesivir & -5.2 & -5.2 & -5.2 & -5.2 \\
Native Ligand & -5.1 & -5.1 & -5.1 & -5.1 \\
\hline
\end{tabular}

\section{Docking Method Validation}

The receptor used in this study was the type of ACE2 receptor with PDBid code: 1R42. In this receptor structure, a native ligand with the name NAG or the chemical name 2-acetamido-2-deoxy-beta-D-glucopyranose is found.

Based on Table 6 above, it was known that the results of the 1 st to 3 rd replications had various RMSD values. This indicated that the native ligand occupied a different docking position, although the position difference was not too big. The difference in position among the replication results was because the docking method used is flexible docking. This condition caused the ligand to be flexible, allowing the ligand to make structural adjustments in order to achieve a stable conformation when it bound to the active side of the receptor. The results showed that there was no significant difference in RMSD values between the 1 st and 3rd replications. This confirmed that the protein interaction with native ligands was very stable, so it tended to maintain its structural position (Muttaqin et al. 2019).

\section{Ligand-Receptor Binding Results}

The visualization of the ligand interaction with the receptor showed amino acid residues from the receptor that played an important role in the binding site area (Arwansyah et al. 2014). To determine whether a compound was predicted to have better activity, a comparison drug compound was used as a control. The test compound that has a lower affinity value than the comparison compound is predicted to have a more stable binding ability than the comparison compound (Suhadi et al. 2019). In addition, the interaction of amino acid residues determines whether the compound has the same biological activity as the comparison or native ligand (Prasetiawati et al. 2021).

Determining the Value of Binding Affinity

Binding affinity is a measure of a drug's ability to bind to a receptor. This value affects the stability of the interaction between the ligand and the receptor in the binding site region. The smaller the binding affinity value is, the higher the affinity is between the receptor and the ligand otherwise, the greater the binding affinity value is, the lower the affinity is between the receptor and the ligand (Prasetiawati et al. 2021). The following was be Table 7 showing the binding affinity values of the test compounds, comparisons and native ligands. Based on the results in Table 7, to find out the better biological activity of the compound, it was necessary to compare the binding affinity value between the test compound with the comparison and native ligand. Based on the results in Table 7, all the test compounds were Dodecanoic acid; Tetradecanoic acid; 7-Amino-8-imino-2-(2-imino-2Hchromen-3-yl); and 1,5,7,10-tetraaza-phenanthren-9-one had a lower binding affinity value than the comparison compound and native ligand. If the binding affinity value of the test compound is smaller than the comparison compound, it is possible that the test compound has better selectivity on the test receptor (Godsell et al. 2021). The lower the binding affinity value is, the stronger the binding power of the ligand to the receptor is. The lower the binding affinity value is, the stronger the bond between the compound and the receptor will 


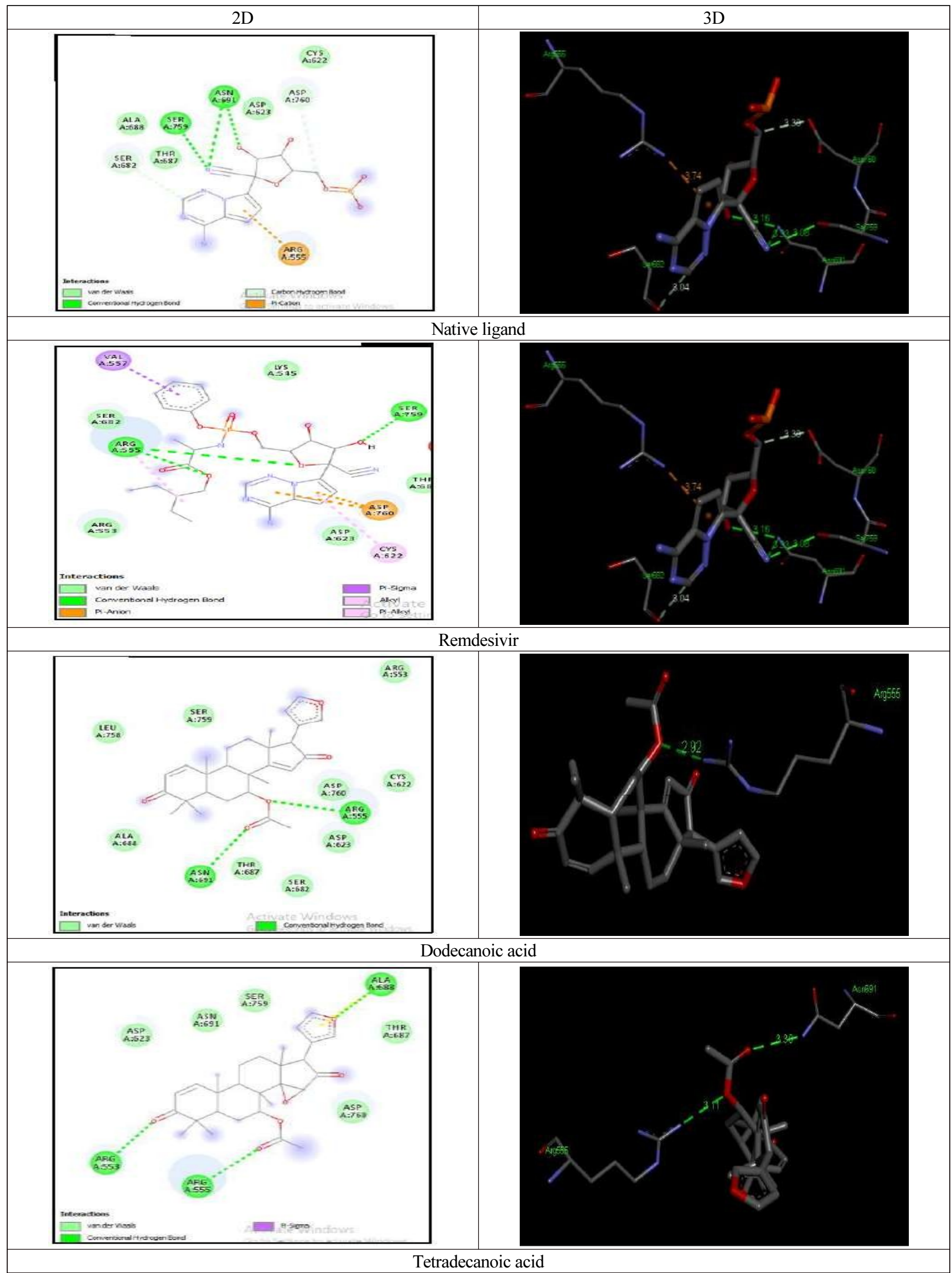

Fig. 4 2D and 3D visualization based on Discovery Studio Visualizer 


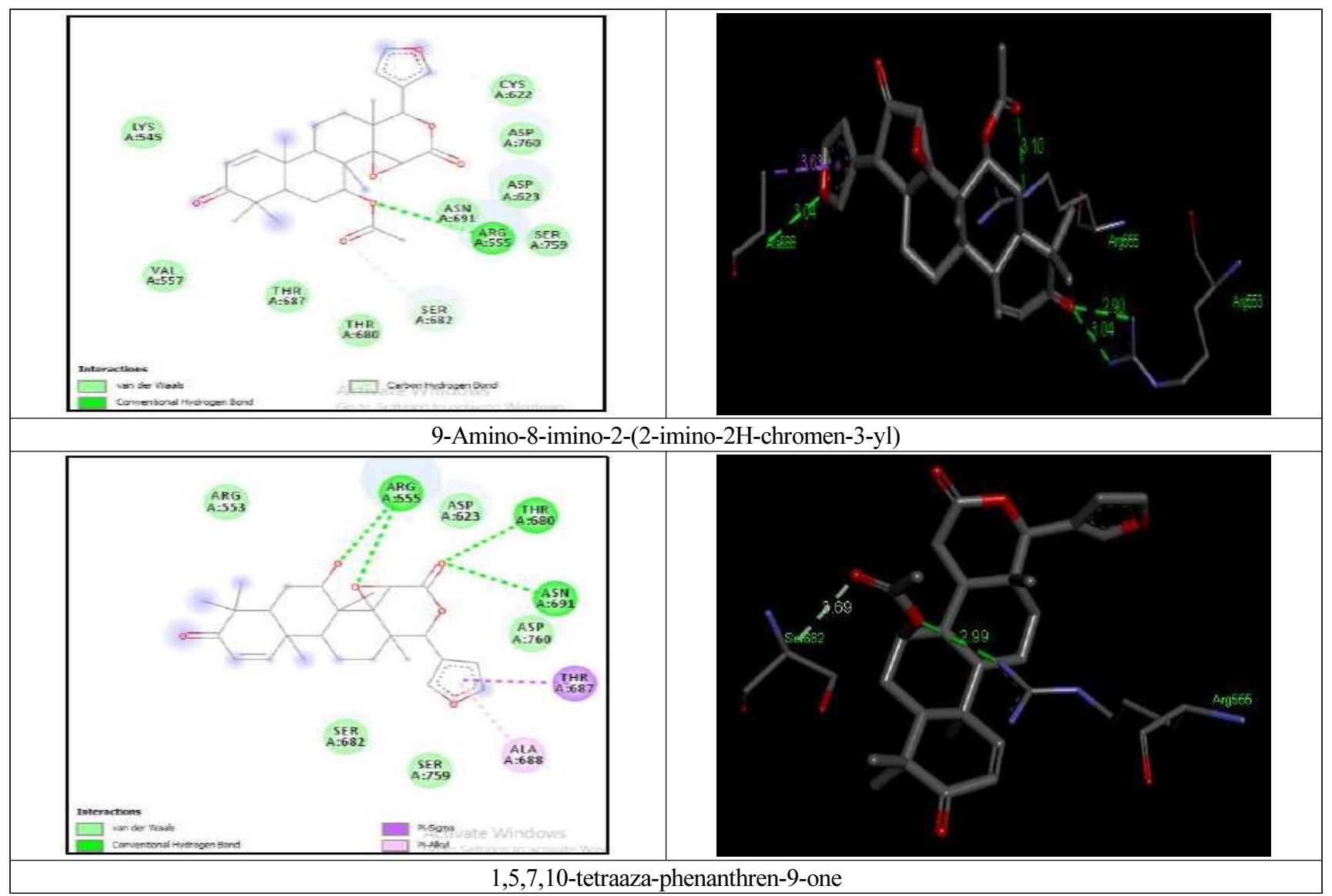

Fig. 4 2D and 3D visualization based on Discovery Studio Visualizer (continued)

be due to the stability and strength of the non-covalent interaction between the compound and the receptor. Thus, it can be said that the test compound in the binding site area interacted more easily than the comparison compound and native ligand (Prasetiawati et al. 2021). From this, it showed that the hanjeli essential oil compound was the most potential test compound as an ACE2 receptor inhibitor (GDP id: 1R42) which was indicated by the lowest binding affinity value compared to other compounds.

\section{Ligand and Receptor Interaction}

The visualization of interactions between ligands and receptors aims to identify residues of receptor proteins that play an important role in the binding site (Arwansyah et al. 2014). The binding site areas of the receptor protein involved amino acid residues that played an important role in binding to the ligand. The interactions that could be observed were hydrogen bonds, hydrophobic interactions and electrostatic interaction; Moreover, the bond distance that occurs is also observed (Prasetiawati et al. 2021). The visualization results showing that the test ligands with amino acid residues and hydrogen bonds that are close to natural ligands showed a similar type of interaction. In this case, they illustrated the similarity of their activities (Prasetiawati et al. 2021). The visualization results of the binding among the native ligand, the test ligand, and the comparison ligand (remdesivir) with the ACE2 PDBid : 1R42 receptor were shown in Figure 4.

Based on the results from Table 8 , it was shown that the native ligand, the test ligand and the comparison ligand interacted with the ACE2 receptor. This was evidenced by the interaction of amino acid residues between the ligand and the receptor. The types of interactions produced were hydrogen bonds, hydrophobic interactions and electrostatic interactions. These interactions determined the strength of the bond between the drug and the receptor. In general, the binding between the drug-receptor was reversible, so the drug would leave the receptor immediately when the drug level in the extracellular fluid decreased. The bonds involved in drug and receptor interactions must be relatively weak but still strong enough to compete with other bonds (Suhadi et al. 2019). Therefore, most of the docking results do not find any covalent bonds because covalent bonds are irreversible even though they produced strong affinity and stable interactions (Prasetiawati et al. 2021).

The results of interaction between ligands and receptors in 
Table 8 Hydrogen bonds, hydrophobic interactions, electrostatic interactions between ligands and receptors

\begin{tabular}{|c|c|c|c|c|c|c|}
\hline \multirow[b]{2}{*}{ No } & \multirow[b]{2}{*}{ Compound } & \multicolumn{3}{|c|}{ Hydrogen Bond } & \multirow{2}{*}{$\begin{array}{l}\text { Electrostatic } \\
\text { interaction }\end{array}$} & \multirow{2}{*}{$\begin{array}{c}\text { Hydrophobic } \\
\text { interaction }\end{array}$} \\
\hline & & $\begin{array}{l}\text { Amino acid } \\
\text { residue }\end{array}$ & Distance $(\AA ̊)$ & $\begin{array}{c}\text { Amino } \\
\text { acid-ligan }\end{array}$ & & \\
\hline \multirow{5}{*}{1} & \multirow{5}{*}{ Native ligand } & Ser759 (A)*** & 3.08 & $\mathrm{~N}-\mathrm{H}$ & Thr687 (A)*** & \\
\hline & & \multirow{2}{*}{ Asn691 (A)* } & 3.33 & $\mathrm{~N}-\mathrm{H}$ & Ala688 (A)* & \\
\hline & & & 3.16 & $\mathrm{O}-\mathrm{H}$ & Asp623 (A)*** & \\
\hline & & $\operatorname{Ser682}(\mathrm{A})^{*}$ & 3.04 & $\mathrm{O}-\mathrm{H}$ & Cys622 (A)* & \\
\hline & & Asp760 (A)* & 3.39 & $\mathrm{O}-\mathrm{H}$ & $\operatorname{Arg} 555(\mathrm{~A})^{*}$ & \\
\hline \multirow{6}{*}{2} & \multirow{6}{*}{ Remdesivir } & \multirow{2}{*}{$\operatorname{Arg} 555(\mathrm{~A})^{* *}$} & 3.09 & $\mathrm{O}-\mathrm{H}$ & $\operatorname{Arg} 553(\mathrm{~A})^{* *}$ & Cys622 (A) \\
\hline & & & 3.15 & $\mathrm{O}-\mathrm{H}$ & Lys545 (A)** & Val557 (A) \\
\hline & & \multirow{4}{*}{$\operatorname{Ser} 759(\mathrm{~A})^{* * *}$} & 2.82 & $\mathrm{O}-\mathrm{H}$ & Asp623 (A)*** & \\
\hline & & & & & Ser682 (A) & \\
\hline & & & & & Thr687 (A)*** & \\
\hline & & & & & Asp760 (A)** & \\
\hline \multirow{8}{*}{3} & \multirow{8}{*}{ Dodecanoic acid } & $\operatorname{Arg} 555(\mathrm{~A})^{* *}$ & 3.11 & $\mathrm{O}-\mathrm{H}$ & $\operatorname{Arg} 553(\mathrm{~A})^{* *}$ & \\
\hline & & \multirow{7}{*}{ Asn691(A)* } & 3.30 & $\mathrm{O}-\mathrm{H}$ & Asp623 (A)*** & \\
\hline & & & & & $\operatorname{Ser682}(\mathrm{A})^{* *}$ & \\
\hline & & & & & Thr687 (A)*** & \\
\hline & & & & & Ala688 (A)* & \\
\hline & & & & & Ser758 (A) & \\
\hline & & & & & Ser759 (A) & \\
\hline & & & & & Asp760 (A)** & \\
\hline \multirow{5}{*}{4} & \multirow{5}{*}{ Tetradecanoic acid } & \multirow{2}{*}{ Arg553 (A) } & 2.90 & $\mathrm{O}-\mathrm{H}$ & Ser759 (A) & \multirow[t]{2}{*}{ Ala688 (A) } \\
\hline & & & 3.04 & $\mathrm{O}-\mathrm{H}$ & Asn691 (A) & \\
\hline & & $\operatorname{Arg} 555(\mathrm{~A})^{* *}$ & 3.10 & $\mathrm{O}-\mathrm{H}$ & Asp623 (A)*** & \\
\hline & & Ala688 (A) & 3.04 & $\mathrm{O}-\mathrm{H}$ & Thr687 (A)*** & \\
\hline & & & & & Asp760 (A)** & \\
\hline \multirow{11}{*}{5} & \multirow{11}{*}{$\begin{array}{l}\text { 9-Amino-8-imino-2- } \\
\text { (2-imino-2H- } \\
\text { chromen-3-yl) }\end{array}$} & $\operatorname{Arg} 555(\mathrm{~A}) * *$ & 2.99 & $\mathrm{O}-\mathrm{H}$ & Lys545(A)** & \\
\hline & & \multirow{10}{*}{ Ser682(A)* } & \multirow{10}{*}{3.69} & \multirow{10}{*}{$\mathrm{O}-\mathrm{H}$} & Val557 (A) & \\
\hline & & & & & Ser759 (A) & \\
\hline & & & & & $\operatorname{Asp} 760(\mathrm{~A})^{* *}$ & \\
\hline & & & & & Asn691 (A) & \\
\hline & & & & & Thr680 (A)* & \\
\hline & & & & & Thr687 (A)*** & \\
\hline & & & & & Cys622 (A)* & \\
\hline & & & & & Asp623 (A)*** & \\
\hline & & & & & Asp618 (A) & \\
\hline & & & & & Tyr619 (A) & \\
\hline & & $\operatorname{Arg} 555(\mathrm{~A}) * *$ & 2.86 & $\mathrm{O}-\mathrm{H}$ & Ser759 (A) & Ala688 (A) \\
\hline & & $\operatorname{Arg} 555(A)^{r *}$ & 2.93 & $\mathrm{O}-\mathrm{H}$ & $\operatorname{Arg} 553(\mathrm{~A})$ & Thr687 (A) \\
\hline 6 & $\begin{array}{l}\text { 1,5,7,10-tetraaza- } \\
\text { phenanthren-9-one }\end{array}$ & Thr680 (A) & 3.05 & $\mathrm{O}-\mathrm{H}$ & Asp623(A) & \\
\hline & & & 3.16 & $\mathrm{O}-\mathrm{H}$ & Ser682 & \\
\hline & & Asn691 (A)* & & $\mathrm{O}-\mathrm{H}$ & Asp760 & \\
\hline
\end{tabular}

Details :

*: amino acids similar to the native ligands

**: amino acids similar to the comparator (remdesivir)

***: amino acids similar to the native ligand and comparator (remdesivir) 
Table 9 Similarities between the native ligand hydrogen bonds and the test and comparison compound hydrogen bond

\begin{tabular}{|c|c|c|c|c|c|c|}
\hline $\begin{array}{l}\text { Amino acid } \\
\text { residue }\end{array}$ & Native ligand & Remdesivir & $\begin{array}{c}\text { Dodecanoic } \\
\text { acid }\end{array}$ & $\begin{array}{c}\text { Tetradecanoic } \\
\text { acid }\end{array}$ & $\begin{array}{c}\text { 9-Amino-8-imino-2 } \\
\text {-(2-imino-2H- } \\
\text { chromen-3-yl })\end{array}$ & $\begin{array}{l}\text { 1,5,7,10-tetraaza- } \\
\text { phenanthren-9-one }\end{array}$ \\
\hline Ser759 & + & + & - & - & - & - \\
\hline Asn691 & + & - & + & - & - & + \\
\hline Ser682 & + & - & - & - & + & - \\
\hline Asp760 & + & - & - & - & - & - \\
\hline Thr680 & - & - & - & - & - & + \\
\hline Ala688 & - & - & - & + & - & - \\
\hline Arg553 & - & - & - & + & - & - \\
\hline Arg555 & - & + & + & + & + & + \\
\hline
\end{tabular}

Tabel 10 Prediction toxicity of the test and comparison compounds

\begin{tabular}{|c|c|c|c|c|c|}
\hline \multirow{2}{*}{ Compound } & \multicolumn{5}{|c|}{ Toxicity } \\
\hline & LD50* & Group LD50* & LD50* & Hepatic toxicity** & Skin irritation** \\
\hline Dodecanoic acid & $555 \mathrm{mg} / \mathrm{kg}$ & IV & No & No & No \\
\hline Tetradecanoic acid & $555 \mathrm{mg} / \mathrm{kg}$ & IV & No & No & No \\
\hline 9-Amino-8-imino-2-(2-imino-2H-chromen-3-yl) & $555 \mathrm{mg} / \mathrm{kg}$ & IV & No & No & No \\
\hline 1,5,7,10-tetraaza-phenanthren-9-one & $274 \mathrm{mg} / \mathrm{kg}$ & III & No & Yes & No \\
\hline Remdesivir & $1000 \mathrm{mg} / \mathrm{kg}$ & IV & No & Yes & No \\
\hline
\end{tabular}

* : Predicted using the Protox Online Tool

** : Predicted using the pkCSM Online Tool

Table 8 showed that the test compounds have an amino acid residue similarity with native ligands and remdesivir as comparison compounds. It was known that all the test compounds have hydrogen bonds at different distances. Hydrogen bonding is a bond that involves the interaction of covalently bonded hydrogen atoms with electronegative atoms such as flour (F), nitrogen (N), oxygen (O) (Muttaqin et al. 2019). In molecular docking, hydrogen bond is the main bond that maintains protein stability (Suhadi et al. 2019).

Hydrophobic interactions are the residue interactions of non-polar amino acids (Prasetiawati et al. 2021). This interaction occurs because some of the amino acid residues on the active side of the protein are hydrophobic (Muttaqin et al. 2019). Hydrophobic interactions also play a role in determining the stability of the ligand toward the receptor (Arwansyah et al. 2014). The results of the hydrophobic interaction analysis among native ligands, test compounds and comparison compounds in Table 8 showed that the test compound Tetradecanoic acid had a hydrophobic interaction with Ala688 residue, while the compound 9-Amino-8-imino-2-(2-imino2H-chromene-3-yl has hydrophobic interactions with Ala688 and Thr682.

One of the strong bonds between the receptor and the ligand was characterized by the number of hydrogen bonds. Test ligands with amino acid residues and hydrogen bonds that are close to natural ligands show similar types of interactions. which in this case describes the similarity of their activities (Arwansyah et al. 2014). To make it easier in looking at the similarity of amino acid residues among native ligands, test ligands and comparison ligands can be seen in Table 9.

Based on Table 9, it can be seen that both the test compounds and the comparison compounds had similar hydrogen bonds with native ligands except for Dodecanoic acid and Tetradecanoic acid compounds. The more hydrogen interactions were between compounds and amino acid residues, the better predicted interactions were between compounds and receptors (Arwansyah et al. 2014). If the test compound bound to the same amino acid residue as the native ligand, it had the possibility of having the same biological activity as the native ligand. Based on Table 9, it is known that all the test compounds have similar hydrogen bonds with the comparison compound (remdesivir). The test compound that has the same hydrogen bonds as the comparison compound may have the same activity as the comparison compound (Prasetiawati et al. 2021).

\section{Toxicity Prediction}

Toxicity prediction is one of the parameters tested in this study. To predict the toxicity of the test and comparison 
compounds, the pkCSM Online Tool and Protox Online Tool sites were used. The parameters tested in the pkCSM Online Tool included skin sensitization, hepatic toxicity (hepatotoxicity), and mutagenicity test with ames (ames toxicity), while the parameters tested on the Protox Online Tool were LD50. Its toxicity class is classified according to the Globally Harmonized System (GHS) and is divided into VI classes based on the range of LD50 values (Muttaqin et al. 2019). The toxicity prediction results of the test and comparison compounds at both sites were carried out by inputting the SMILES code of each compound for further analysis. The following was Table 10 which depicts the toxicity predicted results of the test and comparison compounds.

Based on Table 10, the results of the compound dodecanoic acid and tetradodecanoic acid are predicted was part of toxicity class IV, which is between $300<\mathrm{LD} 502000 \mathrm{mg} / \mathrm{kg}$ which is interpreted as dangerous if ingested (Muttaqin et al. 2019). The compounds gedunin and deacetylgedunin are predicted to be classified as toxicity class III, namely $50<$ $\mathrm{LD} 50300 \mathrm{mg} / \mathrm{kg}$, meaning that they are toxic if ingested. The comparison compound, remdesivir, had an LD50 value of $1000 \mathrm{mg} / \mathrm{kg}$ and belonged to the toxicity class IV, which meant it was dangerous if swallowed.

The prediction of toxicity based on the LD50 value (Lethal Dose 50) associated with a single dose of a substance that could cause the death of 50\% experimental animals (Chagas et al. 2018). The greater the LD50 value is, the safer the material was being tested (Patrick 2001). Based on these facts, the compounds of 9-Amino-8-imino-2-(2-imino-2H-chromen3-yl) and 1,5,7,10-tetraaza-phenanthren-9-one was the ones that have the most toxicity of the other compounds.

Other toxicity predictive parameters tested were skin sensitivity, liver toxicity, and ames mutagenic test. Prediction of skin sensitivity was related to skin allergies due to exposure to certain substances. Based on the results of this test, it was known that both the test compound, namely hanjeli essential oil and the comparison compound, namely remdesivir did not cause a sensitivity reaction on the skin. The same results also work out to the ames mutagenic test parameters, which was that both the test and comparison compounds did not have the potential to be mutagenic. Ames mutagenic testing is one of the most important toxicity tests to assess genotoxic risk. The different results are shown on the toxicity parameters on liver, where there are compounds that are predicted to cause liver toxicity. For example, there were 1,5,7,10-tetraaza-phenanthren-9-one and a comparison compound (remdesivir), while the compounds dodecanoic acid, tetradodecanoic acid, 9Amino-8-imino-2-(2-imino-2H-chromen-3-yl) were the safe compounds and did not cause liver damage (Prasetiawati et al. 2021).

\section{Conclusions}

Based on the results of the study, it could be concluded that:

1. The essential oil compound of the hanjeli plant (Coix lacryma-jobi) complies with Lipinski's five laws.

2. Prediction of toxicity of hanjeli plant essential oil (Coix lacryma-jobi) showed that the compounds of 9-Amino-8imino-2-(2-imino-2H-chromen-3-yl) and 1,5,7,10-tetraazaphenanthren-9-one (toxicity class III: $50<$ LD50 300 $\mathrm{mg} / \mathrm{kg}$ ) are more toxic than dodecanoic acid and tetradodecanoic acid (toxicity class IV: between $300<$ LD50 $\leq$ $2000 \mathrm{mg} / \mathrm{kg}$ ).

3. The compound essential oil of the hanjeli plant (Coix lacryma-jobi) interacted with the ACE2 receptor (1R42) on the active site of the receptor with better affinity than the comparison compound and the original ligand.

\section{Suggestions}

For further researchers, it is hoped that they will be able to carry out binding with a more precise grid box arrangement and explain in more detail the interactions that occur, especially for each amino acid residue involved, so that a more definite mechanism of action can be obtained. In addition, the binding of different types of receptors can be carried out to find out further the prediction of activity on hanjeli plant essential oil compounds.

\section{Conflict of Interest Disclosures}

All Authors have read the manuscript and declared that they have no any conflict of interest.

\section{Authors' Contributions}

DSD, ANS and K designed the experiments, NSH and ANS carried out the experiments. DSD and K supervised the work, DSD, ANS and K revise the manuscript and NSH analyzed the data. All authors contributed to the study. All authors read and approved the final manuscript

\section{Acknowledgement}

The authors thank to the DRPM Kemendikbudristekdikti which has funded this research with the 2021 multi-year basic research scheme numbered DIPA SP DIPA-023.17. The author also expresses appreciation to the research team members from the Department of Biology, Faculty of 
Mathematics and Natural Sciences, Medan State University; Biology Study Program, Faculty of Science and Technology, UIN Ar-Raniry Banda Aceh; Department of Sports Science, Faculty of Sports Science, State University of Medan; Department of Biology, Faculty of Mathematics and Natural Sciences Education, Indonesian Education University, Bandung.

\section{References}

Arwansyah A, Ambarsari L, Sumaryada TI. (2014). Simulasi docking senyawa kurkumin dan analognya sebagai inhibitor reseptor androgen pada kanker prostat. Current Biochemistry 1(1):11-19

Bimonte S, Crispo A, Amore A, Celentano E, Cuomo A, Cascella M. (2020). Potential antiviral drugs for SARS-Cov-2 treatment: preclinical findings and ongoing clinical research. In Vivo 34(3 suppl):1597-1602

Borkotoky S, Banerjee M. (2020). A computational prediction of SARS-CoV-2 structural protein inhibitors from Azadirachta indica (Neem). Journal of Biomolecular Structure and Dynamics, pp. 1-11

Chagas CM, Moss S, Alisaraie L. (2018). Drug metabolites and their effects on the development of adverse reactions: Revisiting lipinski's rule of five. International Journal of Pharmaceutics 549(1-2):133-149

Dahab MA, Hegazy MM, Abbass HS. (2020). Hordatines as a potential inhibitor of COVID-19 main protease and RNA polymerase: an In-Silico approach. Natural Products and Bioprospecting 10(6):453-462

Decaro N and Lorusso A. (2020). Novel human coronavirus (SARSCoV-2): A lesson from animal coronaviruses. Veterinary Microbiology 244:108693

Diningrat DS, Risfandi M, Harahap NS, Sari AN, Siregar HK. (2020). Phytochemical screening and antibacterial activity coix lacryma-jobi oil. Journal of Plant Biotechnology 47(1): 100-106.

Gheblawi M, Wang K, Viveiros A, Nguyen Q, Zhong JC, Turner AJ, Raizada MK, Grant MB, Oudit GY. (2020). Angiotensinconverting enzyme 2: SARS-CoV-2 receptor and regulator of the renin-angiotensin system: celebrating the 20th anniversary of the discovery of ACE2. Circulation Research 126(10): 1456-1474

Goodsell DS, Sanner MF, Olson AJ, Forli S. (2021). The AutoDock suite at 30. Protein Science 30(1):31-43

Helmy YA, Fawzy M, Elaswad A, Sobieh A, Kenney SP, Shehata AA. (2020). The COVID-19 pandemic: a comprehensive review of taxonomy, genetics, epidemiology, diagnosis, treatment, and control. Journal of Clinical Medicine 9(4):1225

Hussein RK, Elkhair HM. (2021). Molecular docking identification for the efficacy of some zinc complexes with chloroquine and hydroxychloroquine against main protease of COVID-19. Journal of Molecular Structure 1231:129979

Kanakaveti V, Shanmugam A, Ramakrishnan C, Anoosha P,
Sakthivel R, Rayala SK, Gromiha MM. (2020). Computational approaches for identifying potential inhibitors on targeting protein interactions in drug discovery. Advances In Protein Chemistry And Structural Biology 121:25-47

Koulgi S, Vinod J, Mallikarjunachari VNU, Uddhavesh S, Rajendra J. (2020). Remdesivir-bound and ligand-free simulations reveal the probable mechanism of inhibiting the RNA dependent RNA polymerase of severe acute respiratory syndrome coronavirus 2. RSC Advances 10(45):26792-26803

Li S, Li S, Disoma C, Zheng R, Zhou M, Razzaq A, Liu P, Zhou Y, Dong Z, Du A, Peng J. (2021). SARS-CoV-2: Mechanism of infection and emerging technologies for future prospects. Reviews in Medical Virology 31(2):e2168.

Lipinski CA. (2004). Lead-and drug-like compounds: the rule-offive revolution. Drug Discovery Today: Technologies 1(4): 337-341

Maia EHB, Assis LC, de Oliveira TA, da Silva AM, Taranto AG. (2020). Structure-based virtual screening: from classical to artificial intelligence. Frontiers in Chemistry 8:343

Muttaqin FZ, Ismail H, Hubbi NM. (2019). Studi molecular docking, molecular dynamic, dan prediksi toksisitas senyawa turunan alkaloid naftiridin sebagai inhibitor protein kasein kinase 2-A pada kanker leukemia. Journal of Pharmacoscript 2(1):49-64

Neldi V, Suharjono S. (2020). Remdesivir: Mechanism and effectiveness for coronavirus disease 2019 (COVID-19). Pharmaceutical Sciences \& Research 7(4):5

Ni W, Yang X, Yang D, Bao J, Li R, Xiao Y, Hou C, Wang H, Liu J, Yang D, Xu Y. (2020). Role of angiotensin-converting enzyme 2 (ACE2) in COVID-19. Critical Care 24(1):1-10

Patrick G. (2001). Instant notes in medicinal chemistry. BIOS Scientific Publishers Ltd.

Prasetiawati R, Suherman M, Permana B, Rahmawati R. (2021). Molecular docking study of anthocyanidin compounds against Epidermal Growth Factor Receptor (EGFR) as anti-lung cancer. Indonesian Journal of Pharmaceutical Science and Technology 8(1):8-20

Pratama KF, Fauzi M, Hasanah AN. (2020). Activity screening and structure modification of trigonelline as new anticancer drug for non small cell lung cancer through In Silico. Indonesian Journal of Pharmaceutical Science and Technology 7(3):90-99

Ren LL, Wang YM, Wu ZQ, Xiang ZC, Guo L, Xu T, Jiang YZ, Xiong Y, Li YJ, Li XW, Li H. (2020). Identification of a novel coronavirus causing severe pneumonia in human: a descriptive study. Chinese Medical Journal 133(9):1015

Rothan HA, Byrareddy SN. (2020). The epidemiology and pathogenesis of coronavirus disease (COVID-19) outbreak. Journal of Autoimmunity 109:102433

Seffernick JT, Lindert S. (2020). Hybrid methods for combined experimental and computational determination of protein structure. The Journal of Chemical Physics 153(24):240901

Setiawan H, Irawan MI. (2017). Kajian pendekatan penempatan ligan pada protein menggunakan algoritma genetika. Jurnal Sains dan Seni ITS 6(2):A68-A72

Suhadi A, Rizarullah R and Feriyani F. (2019). Simulasi docking 
senyawa aktif daun binahong sebagai inhibitor enzyme aldose reductase. Sel Jurnal Penelitian Kesehatan 6(2):55-65

Vaduganathan M, Vardeny O, Michel T, McMurray JJ, Pfeffer MA, Solomon SD. (2020). Renin-angiotensin-aldosterone system inhibitors in patients with Covid-19. New England Journal of Medicine 382(17):1653-1659

Valdés-Tresanco MS, Valdés-Tresanco ME, Valiente PA, Moreno E. (2020). AMDock: a versatile graphical tool for assisting molecular docking with Autodock Vina and Autodock4. Biology Direct 15(1):1-12

Wan Y, Shang J, Graham R, Baric RS, Li F. (2020). Receptor recognition by the novel coronavirus from Wuhan: an analysis based on decade-long structural studies of SARS coronavirus. Journal of virology 94(7):e00127-20

Wiese O, Annalise EZ, Tahir SP. (2021). Molecules in pathogenesis: angiotensin converting enzyme 2 (ACE2). Journal of Clinical Pathology 74(5):285-290

World Health Organization (WHO) (2020). Geneva: World Health Organization. https://apps.who.int/iris/bitstream/handle/10665/ 331865/nCoVsitrep23Apr2020-eng.pdf

Wrapp D, Wang N, Corbett KS, Goldsmith JA, Hsieh CL, Abiona O, Graham BS, McLellan JS. (2020). Cryo-EM structure of the 2019-nCoV spike in the prefusion conformation. Science 367(6483):1260-1263
Wu A, Peng Y, Huang B, Ding X, Wang X, Niu P, Meng J, Zhu Z, Zhang Z, Wang J, Sheng J. (2020). Genome composition and divergence of the novel coronavirus (2019-nCoV) originating in China. Cell Host \& Microbe 27(3):325-328

Xu X, Chen P, Wang J, Feng J, Zhou H, Li X, Zhong W, Hao P. (2020). Evolution of the novel coronavirus from the ongoing Wuhan outbreak and modeling of its spike protein for risk of human transmission. Science China Life Sciences 63(3):457460

Yang Y, Islam MS, Wang J, Li Y, Chen X (2020). Traditional Chinese medicine in the treatment of patients infected with 2019-new coronavirus (SARS-CoV-2): a review and perspective. International Journal of Biological Sciences 16(10): 1708

Yin W, Mao C, Luan X, Shen DD, Shen Q, Su H, Wang X, Zhou F, Zhao W, Gao M, Chang S. (2020). Structural basis for inhibition of the RNA-dependent RNA polymerase from SARS-CoV-2 by remdesivir. Science 368(6498):1499-1504

Zhao Z, Tajkhorshid E. (2021). GOLEM: Automated and robust cryo-em-guided ligand docking with explicit water molecules. Biophysical Journal 120(3):290a

Zheng YY, Ma YT, Zhang JY, Xie X. (2020). COVID-19 and the cardiovascular system. Nature Reviews Cardiology 17(5): 259-260 